\title{
Heidegger and the Questionability OF THE ETHICAL
}

\author{
Eric Sean NeLson \\ (University of Massachusetts Lowell)
}

\begin{abstract}
Despite Heidegger's critique of ethics, his use of ethically-inflected language intimates an interpretive ethics of encounter involving self-interpreting agents in their hermeneutical context and the formal indication of factical life as a situated dwelling open to possibilities enacted through practices of care, interpretation, and individuation. Existence is constituted practically in Dasein's addressing, encountering, and responding to itself, others, and its world. Unlike rule-based or virtue ethics, this ethos of responsive encounter and individuating confrontation challenges any grounding in a determinate or exemplary model of reason, human nature, the virtues, or tradition.
\end{abstract}

Keywords: Confrontation, Encounter, Ethics, Facticity, Individuation, Interpretation

\section{The Trouble with Ethics ${ }^{1}$}

In a lecture delivered in 1946, Jean Wahl expressed the ambivalence of Heidegger's ethics when he claimed in rapid succession that it was merely formal, ambiguously allowed a plurality of possible readings, and was in the end

I wish to express my thanks to Lauren Freeman for her comments on an earlier version of this paper, and for her own research on Heidegger and ethics, which encouraged me to refine the arguments presented here.

${ }^{1}$ Heidegger references, referred to as GA with volume and page numbers, are to the pagination of Gesamtausgabe, Frankfurt: Klostermann, 1976-ongoing, unless noted. The following abbreviations are also used: SZ: Sein und Zeit, sixteenth edition, Tübingen: Niemeyer Verlag, 1985. Translations: Being and Time, trans. J. Macquarrie and E. Robinson, New York: Harper and Row, 1962 and Being and Time, trans. J. Stambaugh, Albany: SUNY Press, 1996. PM: Wegmarken, second edition, Frankfurt: Klostermann, 1978 / Pathmarks, trans. W. McNeill, Cambridge: Cambridge University Press, 1998. 
not an ethics at all. ${ }^{2}$ Notwithstanding some notable efforts at locating the ethical in Heidegger's works, the prevailing perspective of both his defenders and critics continues to reject any ethical dimension to Heidegger's thought. This standard account is not without a basis in Heidegger's own self-interpretation, as he repeatedly denied that his work concerned ethics understood as an ontic domain of inquiry such as sociology or anthropology and was suspicious of the very language of "ethics" and "values." If ethics is an ontic and empirical instead of an ontological issue, and the ontological is transcendentally or dualistically separated from the ontic, then there appears to be no place for the ethical.

The absence of the ethical in Heidegger's works is either due to its being: (1) descriptively neutral, ethically indifferent, or merely disinterested (which can be designated as the value-neutrality or, in Levinasian terms, the ontological indifference thesis $\left.{ }^{3}\right)$, or (2) intrinsically annihilative, violent, and unethical (which might be called the nihilism thesis ${ }^{4}$ ). The former thesis is sometimes considered to be a defense of Heidegger's ontology even though it cannot rescue it from its critics, since it abandons it to them. Critics such as Habermas can then rightly claim that Heidegger's phenomenology remains captured in the unacknowledged and unresolved performative aporias of "crypto-normative" and "transcendental" philosophy, whereas Levinas or Žižek can justifiably contend that the indifference and neutrality of ontology is intrinsically unethical, socially irresponsible, and perhaps evil. ${ }^{5}$

${ }^{2} \mathrm{~J}$. Wahl, Petite histoire de l'"existentialisme," suivie de Kafka et Kierkegaard: Commentaires, Paris: Club Maintenant, 1946. This passage is discussed in S. Moyn, Origins of the Other: Emmanuel Levinas between Revelation and Ethics, Ithaca: Cornell University Press, 2005, p. 204.

${ }^{3}$ This is not to deny some objectifying tendencies in Being and Time that would serve to support this view. It does suggest their tension with the movement toward a more originary thinking of the ethical, as shown in W. McNeill, The Glance of the Eye, Albany: SUNY Press, 1999, p. 94. For Levinas, moral indifference characterizes both ontology and phenomenology as in E. Levinas, Basic Philosophical Writings, Bloomington: Indiana University Press, 1996, pp. 98-100.

${ }^{4}$ An early critique of Heidegger along these lines is found in K. Löwith, Martin Heidegger and European Nihilism, New York: Columbia University Press, 1998, it is also made by Levinas. For a detailed account of the issues of indifference and violence, and their connections, see F. Schalow, The Incarnality of Being: The Earth, Animals, and the Body in Heidegger's Thought, Albany: SUNY Press, 2006, pp. 139-140. On phenomenological neutrality, see R. J. Dostal, "Time and Phenomenology in Husserl and Heidegger," in C. B. Guignon (ed.), The Cambridge Companion to Heidegger, second edition, Cambridge, Cambridge University Press, 2006, p. 138.

${ }^{5}$ The charge of unethical crypto-normativism is made in J. Habermas, The Philosophical Discourse of Modernity: Twelve Lectures, trans. F. Lawrence, Cambridge: MIT Press, 1987, pp. 131-160. For Habermas, post-Nietzschean philosophy remains within the aporias of subjective reason and crypto-normativism (ibid., 97-105, 301), the latter is particularly problematic in discourses presupposing value-neutrality (ibid., 284). Levinas connects the neutrality and indifference of ontology with the unethical, frequently associating it with Heidegger's involvement with National Socialism. See E. Levinas, Basic Philosophical Writings, op. cit., ch. one and six. On formalism, indifference, and the unethical, note S. Žižek, The Parallax View, Cambridge: MIT Press, 2006, p. 87. 
Responding to such criticisms, I suggest that the value-neutrality and the nihilism thesis are unsatisfactory interpretations and, if Heidegger did not eliminate the ethical for the sake of neutrality or anti-ethical nihilism, the question of the ethical needs to be raised anew. The question concerning the ethical import of his critique of ethics as ontic, confused, and derivative requires interrogating the meaning of "ethics" and pursuing whether ordinary and conventional discourses about ethics and values, including those asserting its primacy, disclose or conceal the ethical.

\section{Being without Ethics?}

Heidegger consistently rejected ethics understood as: (1) arbitrary subjective assertions and choices about "worldviews" and "values" and (2) objective and systematic rational or scientific accounts of rules, principles, norms, and axioms. These two ways of conceptualizing ethics characterize the discourse of ethics in the early twentieth-century and presuppose modern accounts of subjectivity and objectivity rooted in the metaphysical tradition. If these discourses exhaust the meaning of ethics, Heidegger cannot be an ethical thinker, since Being and Time aims at the destructuring (Destruktion) of the divisions between subject and object, subjectivity and objectivity, and being and value. If one considers Heidegger's questioning of the division of philosophy into separate disciplines such as ethics and epistemology in addition to the radical disjunction of facts and norms, or the facticity and normativity of transcendental philosophy, the context of Heidegger's problematization of ethics becomes clearer and his doubts concerning ethical theory more plausible insofar as they do not necessarily exclude the ethical in a wider sense. Heidegger's critique did not aim at the various ways one can be ethical. He did not systematically critique previous ethical systems and doctrines, advocate an immoralist or nihilistic rhetoric, nor justify a global moral skepticism. There is no challenge to ethics in the name of the anti-ethical, nor the pretense of transcending the ethical in the value neutrality of impartial scientific objectivity or transcendental neutrality of phenomenological description.

In spite of Heidegger's recurring claims that he is driven by the question of being, and disinterested in ethics as an ontic discipline or subjective assertion about world-views ${ }^{7}$, he intermittently mentioned the possibility of articulating an ethics from the perspective of a worked out "metaphysics of existence." 8 These two claims are incoherent unless the ethical (1) was bracketed rather

${ }^{6}$ On the questionable character of discourses about values, see F. Olafson, Heidegger and the Ground of Ethics, Cambridge: Cambridge University Press, 1998, pp. 92-93, and L. Hatab, Ethics and Finitude, Lanham: Rowman and Littlefield, 2000, pp. 89-91.

${ }^{7}$ GA 26, pp. 18-22, 171.

${ }^{8}$ Ibid., p. 199. 
than eliminated by fundamental ontology and (2) to be re-awakened in a new and alternative sense, a strategy seen in his 1928 project of "metontology" and the metaphysics of human existence. This contention, based on the lecture courses of the late 1920s, is strengthened by the preliminary and incomplete character of Being and Time. Issues not mentioned or discussed - such as ethics, the animal, the body, gender, and sociality - are not necessarily insignificant, particularly if they are further illuminated in related lecture courses and later writings. ${ }^{9}$

In addition to stating that ontology provided a basis for ethics, a claim Heidegger repeated in speaking of an originary ethos of dwelling in the Letter on Humanism, his writings and lectures of the 1920s display their own normative commitments as he employed some varieties of ethically-charged and inflected language. Heidegger modified traditional concepts such that it is unclear if and to what extent they share in their previous religious, metaphysical, and ethical meanings. Responding to this concern by appealing to the non-hermeneutical neutrality of the transcendental or ontological begs the question insofar as it presupposes instead of demonstrating ethical indifference. This visible ethical inflection intriguingly places in question previous portrayals of Heidegger's phenomenology by implicating the most basic concepts of Being and Time. These include authenticity, care, choice, conscience, decision, everydayness, freedom, responsibility, resoluteness, solicitude, the "they" or "one," destruction and tradition, and individuated being-there (Dasein) itself.

Throughout the 1920s, Heidegger used ordinary ethical language in appealing to moral obligations and virtues such as perseverance, loyalty, dignity, courage, and commitment. He did not eliminate but appealed to the exemplary character of various philosophical and other virtues. What can only be described as the virtue of lingering in the question remained a fundamental commitment of his thinking. ${ }^{10}$ Just as Levinas's language fails to escape ontology in its movement toward an ethics without being, Heidegger's idiom is never ontological to the extent that it escapes the ethical.

Lawrence Hatab has argued that authenticity is more appropriately interpreted as an exemplary model or virtue than as a norm, rule, or value. ${ }^{11}$ Given this virtue-ethical tendency in Heidegger's language, if not the mastery and self-sufficiency of the ideal citizen rooted in a definitive and exemplary account of the function and nature of human existence, the phenomenological neutrality thesis does not have much validity. It has none, if Heidegger is not a transcendental or crypto-transcendental philosopher, as he remains for

\footnotetext{
${ }^{9}$ Volumes 26, 27, and 29/30 discuss all of these examples.

${ }^{10}$ Derrida's deployment of terms such as dignity, duty, decision and responsibility in his discussion of the question of the question, and its priority, in Heidegger also points towards its ethical character. Compare S. Critchley, The Ethics of Deconstruction, second edition, Edinburgh: Edinburgh University Press, 1999, p. 96.

${ }^{11}$ On authenticity as a virtue, for example, see L. Hatab, Ethics and Finitude, op. cit., p. 118.
} 
Habermas, but critically confronted transcendental phenomenology for the sake of its hermeneutical and historical-destructuring transformation. This suggests that the transcendental, universal, and formal - which can and should not be eliminated as popular irrationalism assumes - are persistently referred back to the facticity of the singular entangled in and exposed to a concrete and plural nexus of significations and their breakdowns. Heidegger described his early project as the formal indication or hermeneutics of factical life. If this is the most fitting way to understand the strategy of Being and Time, as Kisiel and others have argued ${ }^{12}$, the project of a hermeneutics of facticity cannot be neutral or indifferent. Despite his bracketing of "ethics" as ontic, confused, or non-originary ${ }^{13}$, his thinking remains in some sense ethical. Heidegger might be "ethically challenged" yet he is not "without ethics."

\section{Beyond Neutrality and Nibilism}

The unethical nihilism thesis, associated with Habermas and Levinas, has the merit of being more plausible than the neutrality thesis, as the political and ethical problems of the person appear to seamlessly complement the ethical deficits of the philosophy. As such, this issue is and ought to be more troubling. If one condemns the evil of National Socialism, acknowledges the absolute horror of the Shoah, and wants to avoid being complicit with or an apologist for murder and injustice, can one maintain the ethical significance of Heidegger's philosophy? The polemical literature concerning Heidegger has a valuable role in promoting such questioning.

Given the failure of the neutrality thesis, the only avenue of adequately answering the nihilism thesis, unfolded in various ways from the youthful Arendt and Löwith to Levinas and Habermas, is to exhibit the ethical import of Heidegger's hermeneutical phenomenology. This is not found in what he directly wrote about ethics, since he did not write much, but in what he indirectly indicated about ethics (1) through basic concepts from authenticity and responsibility to responsive encounter and individuating conflict and (2) in the hermeneutical practice, performance, and enactment of his thinking.

At the same time as Heidegger disputed the significance of ethics, interpreted as arbitrary assertions of subjective values and worldviews or as objective value theory, system, and axiology, his philosophical practice exhibits and provokes ethical reflection just as his works invoke and entail individuation through responsibility. The following paragraphs make the case that Heidegger's thought hermeneutically indicates the ethical, although not in order to save Heidegger from his critics. It is an attempt to articulate a demystified and

${ }^{12}$ T. Kisiel, The Genesis of Heidegger's Being and Time, Berkeley: University of California Press, 1993.

${ }^{13} \mathrm{SZ}$, p. 16. 
situated notion of the ethical - if imperfectly achieved in Heidegger's works - which is hermeneutically appropriate to the singularity, individuation, fractured immanence, finitude, and facticity of human existence, including the confrontation with its injustices, suffering, and pain. This ethical prospect is opened up in Heidegger's ontological questioning of being that usually seems so distant from and other than the ethical.

Heidegger's hermeneutics of factical life, explicated through the formal indication and analysis of human existence as the individuating being-there of Dasein, is an interpretive and thus not a purely formal "meta-ethics." Ontology is meta-ethical rather than anti-ethical as it enacts a practice concerned with the possibilities and conditions of the individuation of human existence in the midst of others, things, and the world. Being and Time accordingly presents us with fragments of the ethical that oblige us to appropriate and individuate them anew. The analysis of Dasein is ethical not only because of Heidegger's redefinition of traditional ethical concepts such as authenticity, engaged conscience, freedom, guilt, phronesis, and responsibility but by the enactment or performance of thinking as Begegnung (responsive encounter) and Auseinandersetzung (differentiating confrontation) with things, others, and oneself. Heidegger's interpretive and linguistic practices indicate and enact the ethical through its being-with (Mitsein) as a question addressing, distinguishing, and individuating Dasein as each time singularly its own. The ethical tendency of Heidegger's early language is continued in his later differentiation of the responsiveness of thinking from the mastery of philosophy in the context of mindfulness or attentive reflection (Besinnung) enacting the letting releasement of things (Gelassenheit). Such self-emptying generosity, unselfish yet not thereby without self, contradicts the self-interested and egocentric obsession with one's own death ascribed to Dasein by critics and an immoral nihilism setting up and tearing down values without attentiveness to the beings that ethics is supposed to address.

\section{Logos and the Ethical Event of Communication}

Logos, conventionally translated as language or reason, is a basic word of the philosophical tradition and Heidegger's engagement with it from his early to late works. As a basic word, which Heidegger repeatedly returned to in different contexts, we should consider whether it excludes the ethical or whether the communicative encounter and event of logos discloses an alternative yet nevertheless still ethical dimension. Logos is a formally indicative concept enacted throughout Being and Time. Although Heidegger does not formally discuss the phenomenon of language until later in Being and Time $e^{14}$, the question

${ }^{14}$ SZ, p. 160. 
of language is fundamentally already at work from the opening question of the meaning and sense of being. Via the posing of this question, and the initial discussions of tradition, hermeneutics, phenomeno-logy, and destructuring (Destruktion), Heidegger operates in relation to the question of language as logos, a point that is strengthened by considering the early lecture courses.

In his early hermeneutics, Heidegger is already a philosopher of language and communication as logos or the event of communication. Language not only occurs as talking about (besprechen) something from a third-person objectivating perspective, it is also described as a lived enactment (Vollzug) and address (ansprechen). As Heidegger claimed in 1926, the former predicative statement ("truth about") is rooted in the latter relational encounter ("truth for"). ${ }^{15}$ Dasein only "speaks about" something because it "speaks out" in "speaking with" others. ${ }^{16}$ The structuring of human existence through the communicative event of addressing and being addressed distinguishes the existence of Dasein as dis-covering. ${ }^{17}$ This language of address, of claiming and being claimed, of responding and co-responding, emerged in relation to the question of logos in the earliest lecture courses and continues to inform the responsiveness of poetic language formulated in his later works; his previous and later thought share in this care for the word. The event of address and being addressed, of being claimed and responding to the claim, resonates throughout the transformations of Heidegger's thought.

In the context of discussing Aristotle and the hermeneutical situation in the mid-1920s, Heidegger explicated the relation of logos and being through the address-character of encountering the world: "The world is always encountered in a specific way of being addressed, in being claimed (logos)." ${ }^{18}$ Discourse is "a fundamental determination of Dasein itself" and disclosive logos "is the basic comportment of being-true that Dasein is." 19 The primordial meaning of logos is the communicative event of address and is accordingly prior to and opens the possibility of logos as logic and the communicative action of giving and taking reasons. Logos signifies responding and attending to something as that something. ${ }^{20}$

Heidegger associated language with receptivity already in 1919/20 when he speaks of the phenomenological relationship to the phenomena as one of giving oneself over to (Hingabe) and letting (lassen) rather than positing or

${ }^{15}$ T. Kisiel and T. Sheehan, Becoming Heidegger: On the Trail of his Early Occasional Writings, 1910-1927, Evanston: Northwestern University Press, 2007, p. 287.

${ }^{16}$ Ibid., p. 204.

${ }^{17}$ Ibid., p. 287, and SZ, p. 45.

${ }^{18}$ M. Heidegger, "Phänomenologische Interpretationen zu Aristoteles (Anzeige der hermeneutischen Situation)," in H.U. Lessing (ed.), Dilthey-Jahrbuch, 6: 237-69, p. 241.

${ }^{19} \mathrm{~T}$. Kisiel and T. Sheehan, Becoming Heidegger, op. cit., p. 224.

${ }^{20}$ GA 27, p. 200. 
constituting. ${ }^{21}$ He goes further in describing it as an eros in which one lets oneself go (sich-los-lassen) into life. ${ }^{22}$ Life is gained by giving oneself over to it as is philosophy, which is accordingly not the neutrality of objective meaning, the differentiating concern yet uncaring indifference of everydayness, or the lack of concern with one's own possibilities. ${ }^{23}$ This life, using the language of Lebensphilosophie that he later criticized, is the enactment and practice of the life that one is. Phenomenology as letting-be-seen is not an indifferent and neutral intellectual receptivity, passivity, or collecting. ${ }^{24}$ It is responding receptiveness to how the world shows itself by letting it show itself. Such letting, occurring through the "as," is interpretative and appropriative as entities and world are disclosed as world and as entities of one sort or another. ${ }^{25}$ Heidegger concluded "What is Metaphysics?" later that decade by drawing attention to the need to "allow space for beings as a whole" and "release ourselves into the nothing." 26 This language of allowing, giving, letting, and releasing is not accidental or irrelevant to the strategies and stakes of Heidegger's works. It discloses its ethical dimension, suggesting an alternative to the reduction of the differentiated multiplicity of his thinking to the static "unity" and "totality" of ontology that he himself radically placed in question. ${ }^{27}$

The language of "passivity" is often opposed to that of "activity," as Heidegger's work is reconstructed according to a dialectic of solipsistic Dasein and collective and communitarian Mitsein or "activist decisionism" and "passivist resignation." ${ }^{28}$ These are thought to reflect the arrogant self-assertion of the will and passive submission to irrational natural forces and collectivist anonymity. ${ }^{29}$ Such interpretations problematically conflate the openness of responsiveness with the violence of subordination and subjugation, reducing his thinking to

${ }^{21}$ Note Kisiel's comments on phenomenology as Hingabe in T. Kisiel, The Genesis, op. cit., p. 28.

${ }^{22}$ GA 58, p. 263.

${ }^{23}$ Hingabe is discussed in GA 58, p. 168. Hatab interprets "indifference" as a deficient mode of the empathy of solicitude in L. Hatab, Ethics and Finitude, op. cit., p. 144. Heidegger ascribed a kind of indifference and neutrality to everydayness, although it is absorbed in selfinterest and self-concern, as closing off possibilities for individuation and solicitude.

${ }^{24}$ E. Levinas, Basic Philosophical Writings, op. cit., pp. 96-98. That is, "the indifference of the disclosed" and its "dependen[ce] upon intelligibility" that Levinas describes in the "Truth of Disclosure and Truth of Testimony" as the effacement of the human in Dasein.

${ }^{25}$ On the contrast between the hermeneutic and apophantic "as," see GA 21, pp. 135-161.

${ }^{26} \mathrm{PM}, 96$.

${ }^{27}$ Heidegger clarified this in the mid-1930s. On unity, see GA 65, pp. 41, 209, and 460. On totality, see GA 65, pp. 29, 146, and 323.

${ }^{28}$ Although Moyn perpetuates the opposition between Dasein and Mitsein, he shows how Heidegger's students and critics saw these terms disjunctively as a dilemma rather than Dasein being the individuation of Mitsein in S. Moyn, Origins of the Other, op. cit., pp. 62-87.

${ }^{29}$ On Levinas's critique of the "self-interested decisionism" and the "anonymous indifference of being," see T. Chanter, Time, Death, and the Feminine, Stanford: Stanford University Press, 2001, p. 28. Such a developmental reconstruction is seen in J. Habermas, "Work and Weltanschauung: The Heidegger-Controversy from a German Perspective," trans. J. McCumber, Critical Inquiry 15 (Winter 1989), pp. 431-456. 
one-side of this duality of activist spontaneity and passive receptivity. ${ }^{30}$ However, Heidegger unfolded this different dimension through a mindful responsiveness challenging the binary logic of spontaneity and receptivity. Since it involves being claimed and the interpretive transformative answer, responsiveness is neither pure activity nor passivity. It is this opening, freeing, and letting that allows existence to be interpreted and individuated for oneself.

Individuation does not entail being enclosed within an isolated and reified identity, as it is existence stepping out of itself in the world and allowing the world and others to be significant for it. Heidegger portrays "letting" as primordially being moved and affected:

Letting something be encountered is primarily circumspective; it is not just sensing something, or staring at it. It implies circumspective concern, and has the character of being affected in some way $[\ldots] .^{31}$

This letting-be-encountered is made possible by the primordial activity of the being-there of Dasein, which is described in 1928/1929 as the openness of letting beings be (Seinlassen des Seienden) and as the releasement into beings of Gelassenheit. ${ }^{32}$ As a hermeneutical and communicative encounter occurring in a between rather than within consciousness or the intellect, letting is not only passive comprehension or the letting of consciousness as Levinas asserted. ${ }^{33}$ The question of letting is further complicated, however, because Heidegger is not merely a thinker of responsiveness as receptivity to the diversity of things but more fundamentally of responsiveness caught up in conflict and the singularization of differentiation and individuation. How one responds, as a finite, mortal, and partial being, is inevitably enmeshed with questions of injustice and violence, which Levinas identified with a condition of war. ${ }^{34}$ The interdependence and "between" of responsive encounter and differentiation (Begegnung and Auseinandersetzung) and agonistic conflict (Widerstreit), such as that of earth and world described in the works of the mid-1930s, undermines ethics in its traditional metaphysical sense.

\section{Thrownness, Communicative Address, and Individuating Response}

What does it mean to address (ansprechen) and be addressed (angesprochen)? Address is often interpreted as "appeal" yet this identification is problematic in Heidegger's case. In a note in Metaphysics and Nibilism from the late 1930s,

\footnotetext{
${ }^{30}$ See Heidegger's discussion of spontaneity and receptivity in GA 27, pp. 74-75.

${ }^{31}$ SZ, p. 176.

${ }^{32}$ Heidegger speaks of Seinlassen des Seienden in GA 27, pp. 180 and 198-199 and Gelassenheit in GA 27, p. 214.

${ }^{33}$ E. Levinas, Basic Philosophical Writings, op. cit., p. 6.

${ }^{34}$ E. Levinas, Totality and Infinity: An Essay on Exteriority, trans. by A. Lingis, Pittsburgh: Duquesne University Press, 1979, preface.
} 
Heidegger denies that philosophy should be understood as an "appeal" (appel) that is analogous with either a moral or military command. ${ }^{35}$ The interpolation of philosophy has been explored as a poetics of address and response, of letting (Gelassenheit) as responsiveness in Heidegger's later thinking, yet this reflection already emerges in the early Heidegger. Dasein's factical possibilities are misinterpreted if interpreted as the spontaneity and self-certainty of the modern epistemological subject. Dasein does not exist in general; it exists only as itself. ${ }^{36} \mathrm{It}$ is always already (immer schon) addressed and therefore each time (je) addressed anew as "worldish" (weltlich) and as being-with-others (mitseiend). Dasein resists being thought through the prism of an isolated essence or identity, even if Heidegger later abandoned the early focus on Dasein in favor of being (Sein).$^{37}$

Dasein finds itself thrown into a world in which it occurs and enacts itself through understanding (verstehend-in-der-Welt) and differentiation (auseinandersetzend-in-der-Welt). Contrary to the premises of moral liberalism and communitarianism, this understanding involves Dasein's entire disposition, comportment, and attunement and so is not merely intellectual or a question of calculative rational choice. As understanding is constantly threatened by being shaken, overturned, and transformed, it is also not an unalterable structure of tradition, prejudice, or common life. Two arguments from the Winter semester of 1923/24 indicate that (1) understanding as Auseinandersetzung refuses the closure of prejudice or an imposition of identity on that which is to be understood (verstehen as world-opening rather than totalizing), and (2) encountering (Begegnung) occurs through the openness of address and being addressed, an openness that Heidegger reaffirmed later in the decade when he argued that Dasein has already stepped out of itself into the openness of the other. ${ }^{38}$ The first claim is discernible in Heidegger's remark that freedom is not independence from preconditions and preconceptions but the freedom to abandon these in critically engaging the thing itself. ${ }^{39} \mathrm{We}$ are not

\footnotetext{
${ }^{35}$ GA 67, pp. 26 and 53.
}

${ }^{36}$ GA 27, p. 5.

${ }^{37}$ See GA 61, p. 102 and H. Ruin, Enigmatic Origins: Tracing the Theme of Historicity through Heidegger's Works, Stockholm: Almqvist and Wiksell, 1994, ch. 3. The historicity of Dasein, according to Hans Ruin, is a "dialectic" of self and other, identity and difference (pp. 128-133). Instead of dialectic, suggesting mediation and identity, I describe it as the responsive encounter or differentiating conflict of "verstehende Auseinandersetzung" (GA 61, p. 2) or responsive "Widerstreit."

${ }^{38}$ GA 27, p. 138. Interestingly, given its discussion of self and other, Einleitung in die Philosophie is the course that Levinas attended while studying in Freiburg. This response to Levinas's critique of Heidegger is developed in J. Greisch, "The 'Play of Transcendence' and the Question of Ethics," F. Raffoul and D. Pettigrew (eds.), Heidegger and Practical Philosophy, Albany: SUNY Press, 2002, p. 104.

${ }^{39}$ GA 17, p. 2. The young Heidegger already spoke of Auseinandersetzung in the context of Verstehen: "Es ist prinzipiell alles auf Auseinandersetzung gestellt, auf Verstehen in und aus dieser Auseinandersetzung. Diese existenziell bestimmte verstehende Auseinandersetzung ist 'einseitig' von außen ..." (GA 61, p. 2). Verstehende Auseinandersetzung appears again in the late 1930's in Wege zur Ausprache (GA 13). 
free from and cannot suspend all presuppositions and prejudices in understanding, as liberal moral theory idealistically suggests, yet they are features of understanding and the construction of things that are potentially reversed, revised, and resisted through the differentiation of encounter and confrontation. The second remark affirmed that language and understanding do not necessarily begin in the arbitrary and violent imposition of a verbal, social, or mental construct upon things. The relation of saying and the thing can occur in the disclosive encounter of claiming and being claimed by that thing and its world, by words through which the world speaks and shows itself. ${ }^{40}$

The early Heidegger analyzed understanding as occurring and being enacted in the openness of the encounter. Since Heidegger's worldly and fractured immanence is not the transparent intelligibility of knowing but the emergence and counter-emergence of the thing concealing and unconcealing itself in encountering us, he is not committed to immanence interpreted as a closed, indifferent, and unitary totality. ${ }^{41}$ The fractured and plural openness of Heidegger's being, analogous to Dilthey's Zusammenhang, challenges the reduction of the whole to a systematic totality that sublimates and subordinates each particular to a universal origin or principle. Being is the openness for Heidegger in which freedom as transcendence in worldly immanence ecstatically takes place. The formal indication of the forestructures and prejudices of understanding does not preclude but radicalizes the question of the singularity of its enactment - a uniqueness indicated in the each case of the " $j e$ " - and the alterity of the encountered that potentially places each and my own existence into question..$^{42}$ This being placed and lingering in the question is not nihilistic destruction as it opens up alternative and potentially more genuine possibilities. This recognition of singularization in relation to a worldly, social, and historical nexus intimates an ethos of earthly dwelling and a this-worldly responsibility of and for finite mortals that counters its other-worldly mystification.

As interpretively dispersed into the world rather than transcendentally constituting it, my existence is not self-transparently available to me in self-intuition and self-narrative. Existence is each time factical and consequently confronted and thrown into question by that which resists, interrupts, and escapes it. Self-

${ }^{40} \mathrm{GA} 17$, p. 21 . On the significance of addressing/being addressed, note Heidegger's claim in Logik als die Frage nach dem Wesen der Sprache: "Gesetzt, daß wir alles, was nicht nichts ist, als ein Seiendes oder Sein ansprechen müssen, dann ist auch die Sprache, sollte sie selbst ständig werden" (GA 38, p. 25). Also note in Vom Wesen der Sprache: "Das Wort - nicht als Singular zu Wörtern, nicht ein einzelnes 'Wort', sondern Nennung, Zu-, Anspruch und vor dem und wesentlich Wort des Seins [...]” (GA 85, p. 56).

${ }^{41}$ E. Levinas, Basic Philosophical Writings, op. cit., p. 100.

${ }^{42} \mathrm{On}$ the logic of singularity, and the singularity and plurality of Jemeinigkeit, see F. Raffoul, Heidegger and the Subject, New Jersey: Humanities Press, 1998, pp. 215-221. On the logical and hermeneutical character of formal indication, see my articles: "Questioning Practice: Heidegger, Historicity and the Hermeneutics of Facticity." Philosophy Today 44, 2001 (SPEP Supplement 2000), pp. 150-159; “Die formale Anzeige der Faktizität als Frage der Logik," Heidegger und die Logik, A. Denker and H. Zaborowski (eds.), Amsterdam: Rodopi, 2006, pp. 31-48. 
knowledge is practical rather than theoretical, requiring the decentering of the self in its ordinary self-certainty and absorption in everyday affairs. Philosophy in its ruinating facticity is for the early Heidegger the enactment of such questionability. ${ }^{43}$ This questionability arises because Dasein usually and for the most part takes itself, others, and its environing world for granted in the indifferent familiarity of everydayness. As radically thrown and factically implicated in the world, existence is not simply the openness and clarity of its possibilities, even if the futural and possible have priority over the past and the actual.

Dasein does not constitute, make, or throw itself. The true is not the made, as facticity is not merely its own reified second nature or an easily modified product. Individuated being-there is itself only as thrown into and thus entwined with the world, it does not belong to itself but fundamentally to the world and others. It is not only thrown (geworfen) into the facticity of the world and a particular generation, and hence never the virtuous or vicious master of its world or its others, it is fallen (verfallen) from its own-most possibilities in the facticity of in-different everydayness. Thrownness and fallenness, as two modes of facticity, unalterably constitute and positively characterize Dasein in its finite way of being. The ethical is immanently lived and enacted in the ethos of its dwelling, i.e., in Dasein's art and manner of existing, rather than operating according to an external logic of function, norm, reason, virtue, or even transcendent alterity. The self is responsive to non-self only by being a situated and worldly self that can or cannot be itself. It cannot escape or master its facticity and alterity to itself, as these are constitutive, but only encounter and respond to them. By how or the way it responds, the self flees from or embraces its own thrown and fallen, finite and mortal, condition. Authenticity is not a rule or virtue. It is a communicative event of encounter and only a shifting modification of rather than the overcoming of inauthenticity.

\section{The Facticity of the Ethical}

Giorgio Agamben shows in "The Passion of Facticity" how facticity as fallenness emerges from Heidegger's early interpretation of Saint Augustine, where facticity as "the made" is explicated according to the non-originariness and fallenness of man, as fetish and idol, in contrast with what is made and done by God. ${ }^{44}$ Non-self-originary, human facticius is opposed to the self-originariness of the divine nativus. Demonstrating the positivity of the "originary non-originariness" of Dasein in characterizing it as fallen and ruinated, Heidegger's analysis runs contrary Augustine's Manichean understanding of facticity as mere fetishism and sin. This reading allows us to dispute Levinas's identification of Heidegger's recognition of the finitude,

\footnotetext{
${ }^{43}$ GA 61, pp. 151-155.

${ }^{44}$ G. Agamben, Potentialities, Stanford: Stanford University Press, 1999, pp. 185-204.
} 
immanence, and mortality of existence with abandonment in the darkness of "pagan" idolatry and participation. ${ }^{45}$

Finitude, the impossibility of the pure subject and its self-mastery, is more than an accident or fault externally added to human existence; it is its lived and practiced condition. "Authenticity" is not the overcoming and mastering of finitude. Such a vision is itself an inauthentic flight before one's own unmasterable finitude. As self-relating finitude confronted by infinity, Dasein can at best only be authentically inauthentic or inauthentically authentic:

The authentic being of Dasein is what it is only insofar as it is inauthentically authentic, that is, 'preserved' in itself. [Authenticity] is not anything that should or could exist for itself next to the inauthentic. ${ }^{46}$

One condition is not overcome by a different condition, as both are modifications of and different ways of relating to the same everydayness.

Dasein exists usually and for the most part in everyday indifference, only realizing the openness of its possibilities in the pain and trauma of anxiety, dread, and the deepest boredom - that is, in the disrupting uncanniness of individuating encounters. This unmasterable trauma, as a contingent yet unavoidable break of differentiation, constitutes Dasein's existence in its facticity and possibility. Dasein does not redeem itself or get redeemed from fallenness, since it would then no longer be Dasein. It can only fall into and away from its falling. Fallenness is in each case Dasein's own fallenness from its own possibilities, and thus does not occur from any transcendent height that could be localized or named. Since fallenness and thrownness are an irremovable originary violence and trauma, which Levinas contends cannot be ethical and yet might be the very drama and not merely "tragic" event of the ethical, inauthenticity flees to a reified otherness that it is not and can never be. ${ }^{47}$

Heidegger did not proceed in Being and Time from the individual subject to the world, as modern epistemology did from Descartes' Meditations to Husserl's Cartesian Meditations. Despite Levinas's interpretation, being-with and being-in-the-world are not derivative of an analysis that begins with an individual consciousness or entity. ${ }^{48}$ Such a procedure would miss the very

\footnotetext{
${ }^{45} \mathrm{Ibid}$., p. 189. On Levinas' s polemical equation of Heidegger, "Hitlerism," and paganism in the 1930's and beyond, see S. Moyn, Origins of the Other, op. cit., pp. 96-108, 190-194, 206-207.

46 "Das eigentliches Sein des Daseins ist, was es ist, nur so, daß es das uneigentliche eigentlich ist, d.h. in sich 'aufhebt.' Es ist selbst nichts, was gleichsam für sich neben dem uneigentlichen bestehen sollte und könnte." M. Heidegger, Der Begriff der Zeit, GA 64, p. 81.

${ }^{47}$ E. Levinas, Basic Philosophical Writings, op. cit., p. 18. Heidegger used a similar strategy in approaching the nothing in "What is Metaphysics?" The nothing, revealed in the nihilation in human affairs as prior and irreducible to mere negation, can be borne by Dasein in its thrownness but not mastered (PM, pp. 92-93).

${ }^{48} \mathrm{SZ}$, p. 388.
} 
facticity of Dasein. ${ }^{49}$ If Heidegger does not begin with the everyday self-interested yet basically self-avoiding ego, then a different strategy is called for proceeding through the practical everyday world - and the everydayness of what everyone does usually and for the most part - to the possibility of the individuation and differentiation of Dasein in its everyday being-with-others in its environing world.

\section{Caring for "Who"?}

Although Heidegger did not explicitly discuss language until $\$ 34$ of Being and Time and historicity until $\$ 72$, language and history are already at work from the beginning. The question of being and the ways in which being has remained hidden and unthought is a question of communication and history. The ontological question is therefore connected with - if in its difference irreducible to - the ontic inquiries that Dilthey formulated as the study of language, history, and experience. ${ }^{50}$ Since the ontically oriented empirical sciences, including Dilthey's human sciences, are implicated in the forgetting of being and misinterpretation of Dasein, these are not ontologically abandoned but rethought in the context of the question of being.

Whereas being is addressed through the question of its sense, each Dasein is addressed through the question of "who?" 51 The question of individuated being-there does not concern a "what" (even if thought of as person, soul, or subject) but "who" in $\$ 10$. The question of being is not neutrally disinterested; it is an issue for that being who questions itself and who it is and might be by questioning being. The ways Dasein hears and listens to the question of "who?" is primary to its analysis. Dasein is in being claimed, called upon, and addressed, and in claiming and addressing others, and as such is already involved in and tied to a nexus of worldly and intersubjective significance. However, instead of being a pure receptive listening, Dasein's prospects for hearing are enmeshed in the everydayness that both enables and blocks access to oneself, others, and the world. In its practical self-interest in the usefulness and instrumentality of things and in its immersion in the common life of everydayness, Dasein does not usually relate to its possibilities. Insofar as Dasein belongs (gehört) to and only hears (hört) out of this everydayness, it does not listen toward its possibilities. Everyday Dasein is constantly called upon and claimed by others and things, yet it does not hear much less heed them.

\footnotetext{
${ }^{49}$ SZ, p. 229.

${ }^{50}$ W. Dilthey, Einleitung in die Geisteswissenschaften, B. Groethuysen (ed.), fourth edition, Göttingen: Vandenhoeck und Ruprecht, 1959, p. xviii / Introduction to the Human Sciences. R. Makkreel and F. Rodi (eds.), Princeton: Princeton University Press, 1989, p. 51.

${ }^{51} \mathrm{SZ}$, pp. 1 and 45.
} 
Methodologically or formally speaking, phenomenology is responsiveness itself and, if responsibility begins in the response not only to others but to things and oneself, it is an ethical practice. It continues to be the task of phenomenological interpretation to bracket the "natural attitude," as Husserl described, but in order to open and free the possibilities that Dasein already is. Heidegger thus explained the task of phenomenology as "to let that which shows itself be seen from itself in the very way in which it shows itself from itself." ${ }^{2}$ Philosophy is described as reawakening the originary activity of letting and releasement in the lecture course called Introduction to Philosophy of 1928/1929, where bringing philosophy underway is to "let" it occur in us. ${ }^{53}$ Philosophizing is the letting occur of transcendence, which Heidegger expresses in his later language as the openness of the between, and which is bound to the originary praxis of Dasein of releasement. ${ }^{54}$ Philosophy is subsequently not an act of the spontaneity of being, consciousness, or the will. It is philia as receptivity to things, others, and the world, although the philia of philosophy is a friendship and trust that cannot exclude conflict. ${ }^{55}$ The "spontaneity of the subject," to employ Kant's language, is not an imposition of the subject onto others and the world but a fundamental receptivity and "a letting be encountered, an intrinsic passivity and receptivity." 56 Heidegger evokes his earlier Hingabe when he speaks of receptivity as intrinsically belonging to spontaneity and as a free giving over of oneself in the encounter. ${ }^{57}$

This letting be seen and heard, this answering to something immanently from out of itself, is crucial to opening Dasein's individual possibilities. The question of being cannot be pursued in abstraction from the one who questions, as it concerns "the possibility and necessity of the most radical individuation." 58 The question of the sense of being appears to be the most abstract, empty, and formal question, "but at the same time it is possible to individualize it very precisely for any particular Dasein." ${ }^{59}$ According to the singular-plural logic of formal indication, the concrete is approachable through the empty and formal. ${ }^{60}$ It is in this sense that the plurality of concrete existence is formally indicated through the term "Dasein." Dasein's neutrality

${ }^{52}$ SZ, p. 34, italics added.

${ }^{53}$ GA 27, p. 4.

${ }^{54}$ Gelassenheit (GA 27, p. 401), also note GA 65, p. 26. On Heidegger's understanding of praxis and its role in his thought, see McNeill, The Glance of the Eye, op. cit., pp. 29-39, 99-106.

${ }^{55}$ GA 27, pp. 22-23.

${ }^{56}$ GA 27, p. 74.

${ }^{57}$ GA 27, p. 272. The import of receptivity in Heidegger's reading of Kant is highlighted by the emphasis given to the imagination as operating between sensibility and thought (GA 25).

${ }^{58} \mathrm{SZ}$, p. 38.

${ }^{59} \mathrm{SZ}$, p. 39.

${ }^{60}$ Nancy's account of Heidegger's logic of the singular plural is strengthened by relating it to formal indication. See J.-L. Nancy, Being Singular Plural, trans. R. D. Richardson and A. E. O’Byrne, Stanford: Stanford University Press, 2000. 
opens up and indicates the facticity that it in each case singularly is. Dasein as a factically existing being is already dispersed in the world and its neutrality is consequently in each case "broken" and "shattered." It is a formally indicating neutrality of the non-neutral as, for example, the essence of "neutral Dasein" is in each case to be female or male: "The broken neutrality of its essence belongs to the essence of the human. This essence can only primarily be made into a problem from its neutrality, and only with reference to this neutrality is the rupture of neutrality itself possible." ${ }^{61}$

The strategy of formally indicating the concrete plurality of factical existence suggests that the "normative" practice-orienting dimension at work in the analytic of Dasein is "meta-ethical" in contrast to the codified prescriptions and values of a concrete form of life. Dasein is in part defined by its pragmatic activities in Being and Time, and defined as praxis in a related lecture-course. ${ }^{62}$ It exists practically and ethically in each case in one way or another, but not in one definitive way defined by either rules or virtues, because of the kind of existence that it is. Circumscribed by everydayness and still open to possibilities for engaging its everyday existence, the differentiated and non-indifferent being Heidegger calls Dasein is formally indicated by meta-ethical terms such as responsibility, freedom, conscience, care, and authenticity that inform and transverse individual ways of existing.

In a recent work on reification, Verdinglichung, Axel Honneth argues that Heidegger's care is an interactive participatory practice. ${ }^{63}$ In Honneth's analysis, care is ultimately inadequate by suggesting that the world is primarily disclosed through the "care of the self" in contrast to the recognition (Anerkennung) of the other. ${ }^{64}$ Yet care implicates the individual in the practical world and everydayness of others and things, such that there is not only an ethical relation to the other but to the self and to things. ${ }^{65}$ Contrary to Honneth, Dasein is not merely self-interested in being described as a care of the self. The argument of Being and Time indicates that the constitutive ethos of responsiveness of care leads it to take on the characteristics of things (that is, when a "who" misunderstands itself as a "what") and everydayness (in which the logic of the reified "what" precludes the relational "who"). If Dasein did not see things and hear others, it would not lose itself in absorption in them and conscience would not be the break that calls it back to itself. Dasein's vision and hearing leads it to reify and forget the openness, freedom, and the possibilities of its seeing and listening. Individuation signifies reopening these capacities and possibilities. Moving from Begegnung to Auseinandersetzung, Dasein as care is

\footnotetext{
${ }^{61}$ GA 27, pp. 146-147.

${ }^{62}$ GA 27, p. 177.

${ }^{63}$ A. Honneth, Verdinglichung, Frankfurt: Suhrkamp, 2005, pp. 32-34.

${ }^{64}$ Ibid., pp. 39-41.

${ }^{65}$ On the ethical sense of things, rooted in Heidegger and Zen, see F. Dallmayr, The Other Heidegger, Ithaca: Cornell University Press, 1993, pp. 213-225.
} 
reoriented from its concerned yet uncaring absorption in everydayness to the possibility of individuation through a renewal of its care for its own self and thus of its capacities for encountering others. Others are not then left behind in this transformation as it indicates the deepening of care for others precisely through the care of the self.

Care does not exclude care for the other, although it can and does lose and forget itself in everydayness through which the being of care becomes an objectively present and thingly "what." Nevertheless, care is reawakened through the enactment of the question "who?" It is the "who" who addresses me and who I address as "you." This claim is always singular by singling me and the other out in the "with." ${ }^{\circ}$ In the personal pronouns, "I" and "you," self and other are addressed as beings who are in each case their own: "Because Dasein is in each case mineness (Jemeinigkeit), one must always use a personal pronoun when one addresses it: 'I am,' 'you are."' ${ }^{67}$ The other Dasein is addressed as being in each case its own and as an ecstatically existing "you." It is address (ansprechen) that characterizes the relational individuating "between" (Zwischen) of "being-with" (Mitsein), whereas speaking about (besprechen) characterizes the pragmatically rooted objectivating language of things. ${ }^{68}$

If the other were not each time its own (je mein), the possibility of solicitude and solidarity (Fürsorge) - the care for the other precisely in its own singular mineness ${ }^{69}-$ is foreclosed. The other would only be an object of use (zuhanden) and an objectively present thing (vorhanden), as it is in the logic of everydayness. In recognizing the mineness, the singularization of the "each time," of the other, socialization and individuation are bound together. As the transformation of the uncaring indifferent socialization of everydayness presupposes it, individuation and the recognition of the other's individuation in care do not preclude socialization. The being-with (Mitsein) of co-Dasein (Mitdasein) is irremovable and equiprimordial, ${ }^{70}$ as Dasein is individuated as "who" through solicitude and the "with" in answering others. ${ }^{71}$ Frederick Olafson explicates such solicitude in relation to agape and caritas, which is appropriate considering Heidegger's early interest in charity in St. Paul, Augustine, and Luther. ${ }^{72}$

${ }^{66}$ Compare SZ, pp. 42 and 119 with GA 66, p. 148.

${ }^{67} \mathrm{SZ}, \mathrm{p} .42$.

${ }^{68} \mathrm{SZ}$, p. 45.

${ }^{69} \mathrm{SZ}$, pp. 121-124.

${ }^{70} \mathrm{SZ}$, p. 114.

${ }^{71}$ On the question of the "who" and the import of addressing the other as "you," see M. Heidegger, Logik als die Frage nach dem Wesen der Sprache (GA 38, pp. 33-48).

${ }^{72} \mathrm{~F}$. Olafson, Heidegger and the Ground of Ethics, op. cit., pp. 83-84. On the early religious context of care, see J. van Buren, The Young Heidegger, Bloomington: University of Indiana Press, 1999, ch. 8, especially pp. 170-171. 


\section{The Hermeneutical Ethics of Auseinandersetzung}

Hermeneutics is not an art or technique of interpretation, nor its methodology, but a fundamental determination of the being of Dasein. ${ }^{73}$ Hermeneutics is how Dasein comports itself in the world as understanding (verstehen), which is already (schon) each time ( $j e$ ) attuned (Stimmung) in one way or another finding itself (Befindlichkeit) within the facticity of the world. Levinas has argued that Heideggerian understanding remains Cartesian and intellectualistic. ${ }^{74}$ But understanding is not primarily worldly comprehension from a third-person perspective but more fundamentally moved and attuned through moods in relation to the world in which it finds itself. Dasein is as much thrown as it is possibility, and its possibilities emerge only in relation to its factical life. Its concrete possibilities can only be understood from out of its thrownness in the world and fallenness in everydayness, consequently breaking with and providing means to dismantle idealism. Since the nexus of significance is interrupted, plural, and shifting, and is not merely ideal but practical-factical, the hermeneutical movement toward origins and the whole does not culminate in a final grasping or vision of totality. The interpretive retrieval of the primordial, of authenticity as the encounter with the disruptive breakthrough of the originary, confronts a past that never was present to and cannot be mastered by understanding. The hermeneutical "already," "always" (meaning each not all), and "always already" indicate a "that" prior to all constitution and reflection - that is, the irretrievable and traumatic event of the "it" or "there," which like the "greater reason" spoken of by Nietzsche's Zarathustra precedes the "lesser reason" of "I," "me," and the consciousness of "my" existence. ${ }^{75}$

As the practice of phenomenology is already historical, it is called to recognize its own hermeneutical character in order to appropriate and be appropriated toward its own facticity and historicity. Phenomenology cannot rest with bracketing the world and takes a historical turn in becoming genealogical, generative, and deconstructive. ${ }^{76}$ It thus requires, if it is ever to address the habitual everydayness and the history of metaphysics that informs it, a hermeneutical turn so as to dismantle its own historical context and sedimentation. The movement of destructuring requires dismantling one's own "ownness," tradition, and everydayness to uncover hidden and closed off possibilities. ${ }^{77}$ Interpretation restrains through the transmission of tradition and liberates by disclosing possibilities for transformation and individuation through historical destructuring and differentiating encounter.

Destruktion and Auseinandersetzung are not needed because external structures are imposed upon the lifeworld by alien systems or totalities. They are

\footnotetext{
${ }^{73}$ SZ, pp. 37-38.

${ }^{74}$ T. Chanter, Time, Death, and the Feminine, op. cit., pp. 81-82.

${ }^{75}$ Note SZ, p. 68.

${ }^{76}$ Respectively, $S Z$, p. 11; $S Z$ p. 20; and $S Z$, p. 22.

${ }^{77}$ SZ, pp. 20-21.
} 
implicit in the reproduction of the lifeworld itself in its inauthentic everydayness and are its potential modification rather than its transcendence. Although everydayness excludes and normalizes the unusual and the different, the shocking and the uncanny, these are interwoven in the fabric of everyday life itself. Such possibilities, and the alterity already at work within everydayness itself, are disclosed through what Jaspers called limit experiences and situations. ${ }^{78}$ Limit situations potentially place the self-understanding and the taken for granted familiarity of the everyday, as the indifferent any and every one (das man), into question. In these experiences of the uncanny, the questionability and uncertainty of meaning and existence are revealed. Limits and uncanniness enable further individuation by placing previous individuation in question, which does not transpire through flight or mastery but in embracing the uncanny questionability of being. Because possibilities of and for existence are not ordinarily evident, they are awakened through an understanding that decenters, although it cannot eliminate, everydayness by encountering the uncanny questions of existence in limit experiences such as the deepest anxiety or the profoundest boredom.

The historicity and uncanniness that human existence already is, and thus can potentially encounter, forces the hermeneutical transformation of phenomenological seeing. Hermeneutics brings out the questionability and unfamiliarity of the unquestioned and familiar such that the difference at the heart of identity and the non-transparency of Dasein to itself are disclosed. Dasein does not grasp itself, it is constantly disturbed and anxious in being referred and deferred beyond itself, and is in this sense ecstatic, eccentric, and transcendent. The self is in each case betrayed and endangered in its transcendence-inthe-world, or in "the each time of the facticity of transcendence." "As As such, Dasein does not first observe and inquire but understands and "intuits the world" through encounter, confrontation, and conflict. ${ }^{80}$ Phenomenological lucidity and transparency discloses the factical ruination and non-transparency of thrown and fallen Dasein, which has fallen from the heightening of its own transcendence as stepping out from beings. ${ }^{81}$ Absorbed amidst beings, Dasein does not know itself and remains a question for itself, as it is both closest to and farthest away from itself.

Inexorably drawn, referred, and dispersed beyond itself, the phenomenological receptiveness of human existence fails to "return to the things themselves." Responsiveness is impossible to the extent that it is absorbed and fallen in everydayness and its theoretical offshoots, and therefore fundamentally forgetful and non-responsive to the being that is in question. By following through on this responsiveness, through the disquieting moment and the destructuring of misunderstood traditions, we encounter the non-responsiveness

\footnotetext{
${ }^{78}$ Compare Heidegger's discussion in PM, p. 7; SZ, 301n.

${ }^{79} \mathrm{GA} 27$, pp. 358 and 367.

${ }^{80}$ GA 27, pp. 367-368 and 382-390.

${ }^{81}$ GA 27, pp. 207-208.
} 
of existence in its fundamental difference and uncanniness. Responsiveness, as worldly and historical, is referred to and thus deferred through the necessity of destructuring and conflictual encounter that would reawaken its own most possibilities of hearing and answering.

The encounter with historicity, which some wish to divorce from the ethical, led Heidegger to distinguish the study of history as objective history (Historie) and history as enactment and event (Geschichte). The historical relation to history, the history that Dasein is, is not given and transparent to everyday Dasein, but demands differentiating confrontation. ${ }^{82}$ Without awakening the questionability of historicity, object-history and historiology work to secure everyday life in its self-satisfaction and flight, reifying the transmission of the past such that it prevents its being encountered. ${ }^{83}$ This illuminates Heidegger's statement that tradition equally makes possible and impossible. Whereas tradition "takes way [Dasein's] own guidance, its questioning and deciding" insofar as, "[w] hen tradition becomes master, it does so in such a way that what it 'transmits' is made so inaccessible [...] that it rather becomes concealed" ${ }^{44}$, the language of everydayness, its "idle talk" (Gerede) holds back and discourages "any new questioning and all differentiating encounter." ${ }^{35}$ The ambivalence of tradition, including traditional ethics, points toward interdependence and differentiation, continuity and transformation, as difference is persistently tied to that from which it sets itself apart.

For Heidegger, participation in the openness of the there (da) and with (mit) involves differentiation as much as it does identification. Heideggerian participation is not pagan or mystical absorption. It is differentiating communication, as Dasein is mit-teilend teil-nehmen. ${ }^{86}$ The event of coming together and settingapart in communication shows how Dasein does not escape or master its everyday life, much less others, but occurs only in relation to and by modifying it:

This everyday way in which things have been interpreted is one into which Dasein has grown, in the first instance, without the possibility of extraction. In it, out of it, and against it, all genuine understanding, interpreting, and communicating, all rediscovering and appropriating anew, are performed. ${ }^{87}$

\section{Confronting the Question of Ethics}

This paper has not proposed that Heidegger needs to be an ethicist to be relevant, that he developed an ethics in a comprehensive sense, or that he is an esoteric thinker of a secret doctrine of "ethics without ethics." Nonetheless,

\footnotetext{
${ }^{82}$ SZ, p. 98.

${ }^{83}$ SZ, pp. 19-27.

${ }^{84} \mathrm{SZ}$, p. 21.

85 "[J]edes neue Fragen und alle Auseinandersetzung" in SZ, p. 169.

${ }^{86}$ GA 27, p. 130.

${ }^{87}$ SZ, p. 169.
} 
as Fred Dallmayr has noted, "Heidegger's entire opus is suffused with ethical preoccupations" and rejects prevailing models of ethical discourses rather than ethical questions.$^{88}$ As recent research has confirmed, the ethical dimension of Heidegger's early thinking is irreducible to yet can be clearly elucidated in light of his reception of previous philosophical and religious thinkers, particularly Aristotle. ${ }^{89} \mathrm{I}$ have focused on issues of individuation and difference as questions of praxis, and articulated these questions through the phenomenon of being called or addressed and through the relationship between individuated existence and its everydayness and being-with-others. The individuation of mineness, which is the possibility of decision and choice instead of being a static property or affirmation of egoism, transpires in relation to what is not and cannot be my own and the attuned understanding that Dasein in each case is or is not. As an event, understanding is more than the subjective and solipsistic egoism feared by critics. ${ }^{90}$ No matter how alone, isolated, or solipsistic, the self has the structure of being-in-the-world and being-with-others. ${ }^{91}$ Dasein is its relational socialization and individuation, occurring through address and being addressed (ansprechen and angesprochen), hearing and listening (anhören and zuhören), and claiming and being claimed (Anspruch). Heidegger articulates these through interdependent conflict (Widerstreit) and the interpretive encounter of responsive confrontation (verstehende Auseinandersetzung), ${ }^{92}$ such that the identity and difference of Dasein and Mitsein are modifications of average being-with-one-another (Miteinandersein). These relationships between Dasein and its other repeat and deepen the identity of everydayness or they interruptively occur as individuation in a responsive yet differentiating setting apart (Auseinandersetzung) with the other.

Heidegger further explored this nexus of address and conflict, the communicative event of logos and polemos that initiates the opportunity for consensus and dis-sensus through reasons, in his transitional works of the mid-1930s. In Introduction to Metaphysics, listening confrontation occurs as question and answer concerning the violence and uncanniness of the human. The problematic of "responsive confrontation" is transformed in the Beiträge as it is rethought

\footnotetext{
${ }^{88}$ F. Dallmayr, The Other Heidegger, op. cit., pp. 109 and 130-131.

${ }^{89}$ See especially W. McNeill, The Glance of the Eye, op. cit., ch. 2.

${ }^{90}$ Levinas equates the interest in "being" with an interest in "my own being" to the exclusion of the other. Conatus, will, or social-Darwinistic "survival instinct" is at the root of being and its violence. See E. Levinas, Entre nous: Thinking of the Other, trans. M. B. Smith and B. Harshav, New York: Columbia University Press, 1998, p. xii. R. Bernasconi examines Levinas's critique of Heidegger as relying on the self-assertion of will and ego in a biologistic "struggle for existence" (Kampf ums Dasein) in his paper "Levinas and the Struggle for Existence", published in E. S. Nelson, A. Kapust, K. Still (eds.), Addressing Levinas, Evanston: Northwestern University Press, 2005, pp. 170-184.

${ }^{91}$ J.-L. Nancy, Being Singular Plural, op. cit., p. 96.

${ }^{92}$ Compare the early use of this expression (GA 61, p. 2) with the later use in Wege zur Aussprache (GA 13, pp. 15-21).
} 
out of the "between" and the abyssal divide. In "Wege zur Aussprache" (1937), Heidegger spoke of an interpretive confrontation (verstehende Auseinandersetzung) involving a recognition of the other that does not suppress the difference between self and other. ${ }^{93}$ This is a conflict (Streit) not for the sake of strife but for the other. ${ }^{94}$ The relation of self and other does not demand the identity of recognition, it can occur in the individuation of mutual understanding. For Heidegger, difference (Unter-schied) is announced in hearing ${ }^{95}$ yet we are inexperienced in hearing and our ears are overcome by what prevents such a responsive confrontation and hearing.

Auseinandersetzung is already at work in his early hermeneutics of facticity, ${ }^{96}$ and its weight increases in the mid- and late 1930s. ${ }^{97}$ It is noteworthy that Heidegger's early thinking of violence and conflict is bound to the possibility of a thinking of agon and polemos, which is unfolded in his works as Streit, Widerstreit, and Auseinandersetzung. ${ }^{98}$ Such terms are not only negative; they indicate the complex and plural nexus of factical life and its understanding in the context of the communicative event, history, and thinking of being. These words indicate the originariness of violence and trauma in Heidegger's thought, i.e., a thinking that enables encountering and questioning the constitutive role of violence and trauma in human existence without descending to a glorification of brutality and violence or absorption in a biologistic "struggle for existence" or ideological "battle of world-views." for one's "daily bread" in one of Heidegger's earliest formulations of Sorge,

93 "Verständigung im eigentlichem Sinne ist der überlegene Mut zur Anerkennung des je Eigenen des anderen aus einer übergreifenden Notwendigkeit" (GA 13, p. 16).

${ }^{94}$ GA 13, pp. 15-21.

${ }^{95}$ Compare the discussions of the significance of hearing in GA 55, pp. 238-260; and C. Scott, "Zuspiel and Entscheidung: A reading of sections 81-82 in Die Beiträge zur Philosophie" in Philosophy Today: v. 41, pp. 161-167.

${ }^{96}$ GA 61, p. 2. Also compare GA 59, p. 91; GA 60, pp. 9, 53; GA 63, pp. 5, 32, 72; GA 17, p. 3.

${ }^{97}$ Charles Scott remarks about Auseinandersetzung and hearing: "This Auseinandersetzung in its leonine aspect is also conditioned by an effort on [Heidegger's] part to hear the way in which philosophy presents things, to hear philosophical thinking in a way that is appropriate to it, and to give voice to his differences from it as he encounters it. This hearing aspect that conditions Auseinandersetzung constitutes a Zwiesprache [...]." C. Scott, "Zuspiel and Entscheidung", art. cit., pp. 162-163.

${ }_{98}$ Heidegger deploys such language prior to his focused engagement with Nietzsche in the 1930's. An early source of such language is Dilthey, for whom life and history are not placid identities but conditioned by conflict (Streit) and even an irreconcilable conflict (Widerstreit) undermining the possibility of metaphysical totality. Compare W. Dilthey, Weltanschaunngslehre, B. Groethuysen (ed.), second edition, Göttingen: Vandenhoeck und Ruprecht, 1960, pp. 98, 131-134, 152. The conflict (Widerstreit), difference (Unterschied), and incommensurability of discourses, sciences and worldviews rest in the agonistic multiplicity (Streit) of life.

${ }^{99}$ An extended account of this topic can be found in my paper "Traumatic Origins: History, Genealogy, and Violence in Nietzsche and Heidegger," in B. Babich, A. Denker, and H. Zaborowski (eds.), Heidegger und Nietzsche, Amsterdam: Rodopi, forthcoming. 
but he explicitly rejects the idea that care is part of a "struggle for existence" (Kampf ums Dasein) between entities. ${ }^{100}$ Heidegger is not only warning of a superficial application of Darwinism to social realities but the use of such ideas in the popularized Lebensphilosophie of the time. His Post-World War I confrontation with the "struggle for existence" in Spengler is extended in the late 1930s to biologism, biologically based racism, and the combination of politicized social Darwinism (with its racialized fate) and vulgarized vitalistic Lebensphilosophie (asserting the priority of irrational choice and the decisionistic will) distinctive of National Socialism. ${ }^{101}$

The interdependent difference and responsive conflict "for" - i.e., für, not $u m$ - the other ${ }^{102}$ offers the means of destructuring the agon of wills, self-interest, and self-assertion that critics like Levinas locate in Heidegger. Heidegger argued in the Beiträge that calculative thought concerning the preservation of self and species belongs to the darkening of the world and destruction of the earth. ${ }^{103}$ The posthumously published works of the 1930s increasingly show how Heidegger challenged biologism, gigantism, racism, worship of power, frenzied commitment to the total mobilization of society, and the nihilism of abandoning all thought and reflection in the name of "values." By contrast, Heidegger's other thinking strives for an "other attitude" in which man "does not calculate under the compulsion of utility and from the unrest of consumption." ${ }^{104}$ Heidegger attempted to think the en- and dis-owning event or Ereignis, beyond all agon and even polemos, as the primordial difference (Austrag) and confrontation (Auseinandersetzung) of gods and humans, world and earth, which reveals again ethical preoccupations. ${ }^{105}$ Against the assertion of the will, and its total mobilization of reified values, purposes, and techniques, Heidegger's thought imperfectly suggests the possibility of a different ethos and poetics of responsive dwelling. ${ }^{106}$

Heidegger's hermeneutical meta-ethics, which is not a commitment to or a denial of a particular variety of ethics or set of norms, values or virtues, discloses a plurality of concrete ways of understanding, existing, and dwelling. ${ }^{107}$ On this point, Heidegger is closer to the deontological plurality of goods and ways of life than to its virtue-ethical identity and unity. Žižek criticizes the "formalism" of Heidegger's ethics, which he argues is akin to the formalism of Habermas, failing to note the non-determinate or non-subsumptive character of this non-deontological formalism that discloses the concrete singularity

\footnotetext{
${ }^{100}$ GA 61, p. 90 and p. 134 respectively.

${ }^{101}$ GA 65, p. 482.

${ }^{102}$ GA 27, pp. 22-23 and 327.

${ }^{103}$ GA 65, 277.

${ }^{104}$ GA 51, pp. 4-5.

${ }^{105}$ GA 67, p. 77.

${ }^{106}$ On the ethics of dwelling and its environmental import, see my article: "Responding to Heaven and Earth: Daoism, Heidegger and Ecology," Environmental Philosophy, Vol. 1, No. 2, Fall 2004, pp. 65-74.

${ }^{107}$ PM, p. 21.
} 
and plurality of individuated existence through formal indication. ${ }^{108}$ As it is as much an ethical as a methodological strategy, the formal indication of a plurality of particular ways of dwelling, of being called and answering in return, resists the reduction to the indifference of ethical relativism and the particularism and reactionary nostalgia of one exclusive form of life.

The implicit ethical dimension of Heidegger's thought has been explicated in the context of various forms of ethical theory from communitarianism to cosmopolitanism. ${ }^{109}$ Although these might be legitimate attempts to think with Heidegger beyond Heidegger, insofar as they continue to distinguish his works from their ethical reconstruction, the latter interpretations are highly problematic as accounts of Heidegger's works. Heidegger's questioning of everydayness, the tradition, and self-mastery, and his emphasis on individuation and differentiation challenges the premises of communitarianism and virtue-ethics; while universalism, humanism, and cosmopolitanism continue to be problematically part of the history of metaphysics and inadequate to the event, enactment, and ethos or ethical art of human existence.

\section{Conclusion}

Factical and finite practical life, individuating itself through its practical interpretive practices, is already ethical. Unlike the theoretical discourses of ethics, this sense of the ethical is not regional or secondary, since it is the ethos, dwelling, and being-in-the-world of human existence itself. ${ }^{110}$ As existence, the ethical does not consist of rules or virtues to be followed or aimed at or something to be added on to existence.

The question whether ethical responsiveness and attentiveness to the particularity of the situation and singularity of the other is enough to generate ethics requires further investigation. Given that the ethical has been portrayed here through attunement, comportment, and an ethos or art of existing, can it transcend the self of Dasein to ethical alterity? Can one arrive at the ethical, which is often thought of in terms of duties, obligations, and responsibilities, through such letting be and releasement without introducing a more robust responsibility and capacity for ethical deliberation, especially in situations of conflict between two phenomena or ethical claims?

This paper has taken the first steps in responding to such questions to the extent that (1) the ethical import of Heidegger's philosophy transcends both indifferent neutrality and nihilism and (2) it can be a perceptive contribution to articulating the import of the ethical despite - and as a basis for critique

${ }^{108}$ S. Žižek, The Parallax View, op. cit., p. 87.

${ }^{109}$ See L. Vogel, The Fragile "We”, Evanston: Northwestern University Press, 1994, pp. 120 125 , on the possibility of a cosmopolitan reconstruction of authenticity.

${ }^{110}$ See the discussion of the later Heidegger and Derrida on the historically derivative character of the discourse of ethics in S. Critchley, The Ethics of Deconstruction, op. cit., pp. 15-16. 
of - his own reprehensible personal involvement in the extremist nationalism of National Socialism during the early 1930s. His meta-ethical analysis is irreducible to or at least not refuted by the ethics of his own individual practices. If responsiveness and generosity towards others and things can be distinguished from hierarchical subordination, i.e., being claimed by and generously responding to others and things differentiated from being passively subjected to and violently dominated by irrational powers, then the ethics of facticity, finitude, and individuation sketched in this paper can be more than a fragmentary hint of the ethical. ${ }^{111}$ Even if the preceding claim is excessively hopeful, Heidegger remains pertinent for the myriad ways in which his works continue to signify the questionability of the ethical - a questionability that cannot be rightfully said to exist exclusively in the past.

${ }^{111}$ This is further developed in my article: "Heidegger and the Ethics of Facticity," in F. Raffoul and E. S. Nelson (eds.), Rethinking Facticity, Albany: SUNY Press, 2008, pp. 129-147. 
Copyright of Studia Phaenomenologica is the property of Romanian Society for Phenomenology and its content may not be copied or emailed to multiple sites or posted to a listserv without the copyright holder's express written permission. However, users may print, download, or email articles for individual use. 